\title{
Kecenderungan Perilaku Body Shaming dalam Serial Netflix "Insatiable"
}

\author{
Dea Tiara Sandinia Amri \\ Program Studi Ilmu Komunikasi, Universitas Muhammadiyah Yogyakarta, Indonesia \\ tuitiara@yahoo.com \\ Submitted: 4 February 2020; Revised: 2 March 2020; Accepted: 2 March 2020
}

\begin{abstract}
This study aims to determine how much the percentage of body shaming elements in the series "Insatiable" on Netflix. Body shaming scenes are often inserted in various movie genres. One of them is in the comedy genre. This study uses quantitative descriptive methods with the content analysis of the Holsti model. The results of this study indicate that 'Insatiable' have a tendency for body shaming in private space is greater than in public space which is $88,7 \%$. Where it is dominated by verbal body shaming by $87,6 \%$, in the form of personal monologue, by judging their body shape and characteristic personally 39 times.

Keywords: Body Shaming, Content Analysis, TV Series
\end{abstract}

\section{Abstrak}

Penelitian ini bertujuan untuk mengetahui seberapa besar persentase elemen body shaming dalam seri "Insatiable" di Netflix. Adegan body shaming sering disisipkan dalam berbagai genre film. Salah satunya adalah genre komedi. Penelitian ini menggunakan metode deskriptif kuantitatif dengan analisis isi dari model Holsti. Hasil penelitian ini menunjukkan bahwa 'puas' memiliki kecenderungan untuk melakukan body shaming di ruang pribadi lebih besar daripada di ruang publik yaitu $88,7 \%$. Dimana ia didominasi oleh tubuh verbal yang dipermalukan sebesar $87,6 \%$, dalam bentuk monolog pribadi, dengan menilai bentuk dan karakteristik tubuh mereka secara pribadi sebanyak 39 kali.

Kata Kunci: Analisis Konten, Body Shaming, Serial TV

\section{PENDAHULUAN}

Kemudahan akses media yang ditawarkan sekarang ini seperti tidak memiliki batas dan memiliki beragam cara untuk menikmatinya, ada TV, Youtube, Netflix, Hooq dsb. Netflix menjadi salah satu platform hiburan yang populer dan paling laris secara global untuk mengakses judul-judul film populer hingga serial yang eksklusif dan original secara legal (Pratomo, 2018). Sepanjang tahun 2018, Netflix berhasil mencetak prestasi yang cukup gemilang. Layanan streaming video ini mencatat bahwa jumlah pelangganya di seluruh dunia sudah menembus 139 juta dari sebelumnya mereka memiliki 110 juta pelanggan. Artinya ada 29 juta pelanggan baru yang mendaftar layanan Netflix sepanjang 2018. Dari jumlah tersebut ada 8,8 juta pelanggan yang bergabung sepanjang kuartal keempat 2018. Menariknya, sebanyak 7,3 juta berasal dari luar Amerika Serikat (Rahman, 2019).

Pada akhir tahun 2018 Netflix merilis sebuah daftar yang berisi judul-judul film dan serial terpopuler tahun 2018. Insatiable menjadi salah satu serial yang masuk daftar terpopuler saat itu. Tayang perdana di Netflix pada 10 Agustus 2018 bercerita mengenai kehidupan SMA Patty, yaitu perempuan yang gemuk sehingga selalu dirundung oleh teman-temannya. Suatu hari, Patty tiba-tiba menjadi kurus setelah liburan musim panas. Semua takjub dengan perubahan pada dirinya yang signifikan dan membuatnya menjadi orang populer di SMAnya. Namun tujuan dari perubahan fisiknya adalah membalaskan dendam terhadap orang-orang yang pernah melakukan body shaming terhadapnya.

Selama 12 episode serial itu menayangkan banyak sekali perilaku body shaming dalam berbagai bentuk baik yang dilakukan di ruang publik maupun ruang privat. Body shame merupakan peneliaian seseorang 
mengenai tubuhnya yang menimbulkan rasa malu karena penilaian orang lain terhadap bentuk tubuh ideal yang tidak sesuai dengan tubuhnya (Sakinah, 2018). Konsep shame lain, dalam konteks body shaming Ketika seorang wanita gagal mencapai standar katrakter atau bentuk tubuh dengan kata lain merasakan perbedaan antara diri mereka yang sebenarnya dan diri mereka yang diidealisasikan secara budaya, mereka merasa malu. Timbulnya perasaan malu ini yang memunculkan pikiran atau ide-ide untuk merubah tubuh mereka (Choma, Shove, Busseri, Sadava, \& Hosker, 2009).

Serial bergenre dark comedy yang disutradarai oleh Lauren Gussis ini menjadi serial Netflix paling dibenci dan mendapat banjir kritik serta kecaman publik karena mengungkap isu body shaming yang dinilai membawa pengaruh buruk terhadap pandangan yang berkembang di masyarakat yang melanggengkan penyakit dari budaya diet dan objektifikasi tubuh wanita (Khoiri, 2018). Terlebih akan tayang 'Insatiable season 2' pada akhir 2019 ini.

Isu body shaming telah menjadi isu internasional. Fenomena bagaimana tubuh manusia dikonstruksi oleh sosial dan media, Body shaming adalah salah satunya, bagaimana seseorang dinista, dihina dan diintimidasi melalui tubuhnya yang berefek pada hancurnya diri dan hilangnya rasa cinta dan syukur atas karunia tubuh dari sang pencipta (Febrianty, 2018). Pada tahun yang sama di Indonesia Polisi telah menangani setidaknya 966 kasus body shaming sepanjang 2018 (Santoso, 2018).

Tahun 2017 para peneliti bidang kesehatan masyarakat dari Wiratama Institute Ira Dewi Ramadhani mengungkapkan bahwa mayoritas atau sebanyak 51,2\% siswa disalah satu Sekolah Lanjut Tingkat Atas (SLTA) di Semarang mengaku tidak puas dengan penampilan fisiknya (GOR, 2017). Kemudian terdapat fakta mengejutkan dilansir dari Study Fit Rated, 92,7\% dari 1.000 wanita pernah mengalami body shaming. Dan ironisnya, body shaming seringkali datang dari sesama wanita atau orang terdekat.

Insatiable bukan menjadi satu-satunya bukti objektifikasi tubuh yang dilanggengkan media. Beberapa acara televisi di Amerika seperti Bulging Brides, Celebrity Fit Club, Honey, We Killing the Kids dan The Biggest Loser ada dalam konteks budaya yang membenci kegemukan. Pemirsa melihat para kontestan cara mereka terpancing makanan yang menggoda dan sebuah hukuman olahraga yang berat (Farrell, 2011).

Untuk itulah dalam penelitian ini, peneliti hendak meneliti apa saja yang menjadi indikator dan bentuk-bentuk body shaming dalam serial Insatiable ini. Peneliti ingin memaparkan indikator yang mana atau bentuk body shaming yang paling banyak muncul dalam serial Insatiable ini menggunakan jenis penelitian deskriptif kuantitatif melalui metode analisis isi. Penggunaan analisis isi bertujuan untuk mendapatkan gambaran mengenai karakteristik isi dan menarik inferensi dari isi yang bersifat objektif, valid, reliable dan dapat direplikasi (Eriyanto, 2011).

Penelitian terdahulu dari penelitian ini yaitu jurnal oleh Lisyeana Prawiyadi, Gusly Irawan Aritonang, Chory Angela Wijayanti, Prodi Ilmu Komunikasi, Universitas Kristen Petra Surabaya dengan judul Analisis isi pesan bullying dalam serial Netflix "13 Reasons Why". Penelitian analisis isi pesan bullying dalam serial Netflix "13 Reasons Why" dilakukan untuk mengetahui bagaimana tindakan bullying yang terkandung dalam serial tersebut. Perbedaan penelitian ini dengan penelitian terdahulu tersebut yang pertama adalah lebih relevan dan terkininya subjek penelitian. Seperti yang diketahui serial "13 Reasons Why" rilis pada maret 2017 sedangkan serial Insatiable baru saja rilis kurang dari satu tahun yang lalu dan menjadi perbincangan atas kontroversinya yaitu banjir kritik dan kecaman serta petisi penolakan penayanganya di Netflix yang sudah ditandatangani oleh 236.379 orang. Hal inilah yang membuat serial Insatiable lebih baik digunakan sebagai subjek penelitian mengenai kecenderungan perilaku body shaming yang terdapat di dalamnya. 
Kemudian yang kedua, pada penelitian "13 Reasons Why", indikator yang digunakan hanya indikator bullying verbal, fisik, relasional, emosional atau psikologis, seksusal verbal, seksual fisik, seksual relasional, cyber bullying. Sedangkan di penelitian ini akan menggunakan indikator dari bullying verbal, emosional atau psikologi, relasional, kemudian kualifikasi tindak pidana menurut Kitab Undangundang Hukum Pidana pasal 315 KUHP. Hal ini menunjukan hasil penelitian nantinya akan lebih mendetail mengenai ruang lingkup, indikator dan bentuk-bentuk body shaming.

Dengan berbagai fakta dan data yang disajikan di atas, artinya ada banyak penonton dari seluruh dunia khususnya kalangan remaja khususnya remaja perempuan yang ikut mengikuti tayangan atau setidaknya tau mengenai serial Insatiable. Dengan demikian, betapa populernya serial ini. Menandakan bahwa telah banyak penonton yang telah terpapar oleh perilaku body shaming yang disampaikan melalui serial ini. Sehingga peneliti ingin meneliti "Seberapa besar persentase kecenderungan perilaku body shaming yang terdapat dalam serial Netflix 'Insatiable"?

\section{KERANGKA TEORI}

Serial adalah sebuah program acara yang ditayangkan secara berkelanjutan yang terdiri dari episodeepisode. Biasanya nama dari programnya harus sama, tetapi sub judul dapat berbeda, biasanya pemeran/bintang/aktor dalam setiap episodenya memiliki peran yang sama (Perebinosoff, Gross \& Gross, 2005). Dalam penelitian ini, Insatiable merupakan sebuah serial, yakni rangkaian drama yang dikemas berkelanjutan terdiri dari 12 episode. Untuk itulah serial ini menjadi subjek dalam penelitian analisis isi ini, dimana pesan-pesan yang disampaikan berkesinambungan sebanyak 12 episode, sehingga dapat lebih terlihat kecenderungan perilaku-perilaku body shaming yang ingin diteliti

Maraknya sinetron remaja yang menampilkan artis cantik dan langsing serta penggunaan public figure atau model-model cantik, tinggi dan langsing dalam iklan-iklan di media massa memberikan pengaruh yang kuat dalam membentuk presepsi seseorang terutama remaja tentang bentuk tubuh ideal. Hasil serupa diperoleh pada penelitian yang dilakukan Handayani di SMAN 1 Pamulang Jakarta. Dimana proporsi remaja yang mengalami distorsi citra tubuh lebih banyak ditemukan pada kelompok remaja dengan pengaruh media massa yang besar yaitu sebesar 26,3\% (Maigoda \& Briawan, 2013).

Orang-orang berlomba untuk menjadi sama dengan standar. Karena sesuatu atau seseorang yang dianggap berbeda baik dari segi perilaku, identitas diri, bentuk wajah, gesture, kehidupan sosial atau yang lainnya akan rentan penjadi objek bully (Widodo, 2016). Salah satu bentuk penindasan baik verbal, psikologis dan relasional terhadap bentuk atau karakter fisik seseorang bisa didefinisikan sebagai body shaming.

Body shaming sangat erat kaitannya dengan citra tubuh yaitu mengenai pembentukan presepsi tubuh ideal menurut masyarakat, sehingga muncul standar kecantikan yang membuat seseorang merasa rendah diri apabila tidak bisa mencapai standar tersebut. Kemudian seseorang yang tidak bisa memenuhi standar lantas mendapat perlakuan yang berbeda, seperti sindiran baik sengaja maupun tidak sengaja, hal tersebut bisa dikategorikan sebagai tindakan kekerasan verbal atau lebih umumnya dikenal dengan istilah body shaming (Anggraeni, Pranayama, \& Sutanto, 2018).

Bentuk-bentuk body shaming ditinjau dari pasal 315 Kitab Undang-undang Hukum Pidana Indonesia (KUHP), yang menyatakan "Tiap-tiap penghinaan dengan sengaja yang tidak bersifat pencemaran atau pencemaran tertulis yang dilakukan terhadap seseorang baik di muka umum dengan lisan atau tulisan maupun di muka orang itu sendiri dengan lisan atau perbuatan atau dengan surat yang dikirimkan atau diterimakan kepadanya, diancam karena penghinaan ringan dengan pidana penjara paling lama empat bulan dua minggu atau pidana denda paling banyak empat ribu lima ratus rupiah" (Putra, Arista \& Rusdiana, 2019). 
1. Ucapan Body Shaming

Bentuk-bentuk ucapan body shaming antara lain memaki, menghina, menjuluki, meneriaki, mempermalukan di depan umum, menuduh, menyoraki, menebar gossip, memfitnah, mencibir (Yayasan Semai Jiwa Amini, 2008).

2. Tindakan Body Shaming

Bentuk-bentuk tindakan body shaming antara lain memandang dengan sinis, mendiamkan, mengucilkan, memandang yang merendahkan (Yayasan Semai Jiwa Amini, 2008).

3. Bentuk-Bentuk Body Shaming Menurut Hellosehat.com

Menganggap tubuhnya paling gemuk, padahal kenyataanya tidak, menyuruh orang lain untuk olahraga, senang membandingkan tubuh orang lain, mengomentari makanan orang lain (Safitri, 2018).

4. Bentuk-Bentuk Ucapan Body Shaming Menurut Rimma.co

"Kamu kelihatan makin gemuk deh, diet dong!"

"Kamu pede banget sih pakai baju yang nggak sesuai tubuh gitu."

"Kalau kulit gelap gitu, gimana mau keliatan cantik"

"Yakin makan sebanyak itu, pipi kaya bola tuh!"

"Lagi banyak pikiran ya? Jerawat di mukan makin numpuk gitu."

"Kalau terlalu kurus gitu kau enak ya, bisa makan apapun." (Nurmaliana, 2018).

5. Bentuk-Bentuk Tindakan Dan Ucapan Body Shaming Menurut Wolipop.detik.com

Mengungkapkan keprihatinan terhadap bentuk tubuh seseorang

Ekspresi kaget ketika ada orang gemuk olahraga

Memberi saran soal pakai baju

Menghakimi cara diet seseorang

Pujian yang tidak pada tempatnya

“Kamu lumayan cantik untuk ukuran...”(Hestianingsih, 2018).

\section{METODE PENELITIAN}

\section{KONSEPTUALISASI PENELITIAN}

Body shaming didefinisikan sebagai berikut: kondisi dimana seseorang dinista, dihina dan diintimidasi melalui tubuhnya yang berefek pada hancurnya diri dan hilangnya rasa cinta dan syukur atas karunia tubuh dari sang pencipta (Febrianty, 2018). Secara umum korban adalah seseorang yang memiliki karakter fisik yang dimiliki banyak orang atau standar cantik yang berlaku. Metode yang digunakan dalam penelitian ini adalah metode analisis isi kuantitatif. Teknik ini dipilih karena utamanya dipakai untuk menganalisis media baik cetak maupun elektronik. Di luar itu, analisis isi juga dipakai untuk mempelajari isi semua konteks komunikasi, baik komunikasi antar pribadi, kelompok, ataupun organisasi. Asalkan terdapat dokumen yang tersedia, analisis ini bisa diterapkan (Eriyanto, 2011). Indikator yang digunakan dalam penelitian ini ada 3 jenis yakni jenis body shaming lisan, tulisan dan perbuatan. Tiga jenis indikator ini nantinya aka ditabulasi silangkan sehingga akan memperkaya hasil penelitian, tidak hanya memaparkan bentuk-bentuk body shaming saja melainkan konteks body shaming juga.

\section{SUBJEK PENELITIAN}

Populasi dalam penelitian ini adalah seluruh episode serial Netflix Insatiable yang dirilis streaming website pada 10 Agustus 2018 yang berjumlah 12 episode. Dikarenakan populasi yang tidak banyak yaitu 
12 episode, maka peneliti menggunakan seluruh jumlah populasi sebagai sampling penelitian. Dengan demikian, pengukuran tiap sampel akan lebih detail dan terukur.

\section{ANALISIS DATA}

Analisis data dalam penelitian ini mengacu pada tahapan-tahapan dalam melakukan analisis isi, yang pertama akan menentukan permasalahan terlebih dahulu yang akan dirumuskan dalam rumusan masalah. Konsep itulah yang nantinya akan diukur, yakni dalam penelitian kecenderungan perilaku body shaming yang terdapat dalam serial Netflix Insatiable. Kedua, menyusun kerangka berpikirnya sehingga terlihat gejala-gejala apa yang akan diteliti, yaitu dalam penelitian ini perilaku-perilaku body shaming yang ditampilkan dalam serial Netflix Insatiable. Ketiga menyusun perangkat metodologi yakni: (1) Menentukan metode pengukuran atau prosedur operasional, (2) menetukan populasi dan sampel, (3) Menentukan metode pengumpulan data, dan (4) Menentukan metode analisis. Yang terakhir, analisa dan interpretasi data, merupakan analisa terhadap data yang berhasil dikumpulkan peneliti melalui perangkat metodologi tertentu (Bungin, 2011).

\section{HASIL DAN PEMBAHASAN}

KECENDERUNGAN PERILAKU BODY SHAMING DALAM SERIAL NETFLIX

Dari hasil pengkodingan yang dilakukan oleh dua coder, berikut ini adalah temuan data atau kecenderungan perilaku body shaming yang terdapat dalam serial Netflix Insatiable.

\begin{tabular}{cccccccc}
\hline Eps & M & CR & \% & Lisan & Tulisan & Perbuatan & Keterangan \\
\hline 1 & 12 & 0.75 & 75 & 25 & 1 & 3 & Reliable \\
2 & 13 & 0.8125 & 81.25 & 8 & 1 & 0 & Reliable \\
3 & 12 & 0.75 & 75 & 16 & 0 & 0 & Reliable \\
4 & 11 & 0.6875 & 68.75 & 4 & 2 & 0 & Tidak Reliable \\
5 & 13 & 0.8125 & 81.25 & 5 & 1 & 0 & Reliable \\
6 & 14 & 0.875 & 87.5 & 7 & 0 & 2 & Reliable \\
7 & 15 & 0.9475 & 94.75 & 0 & 0 & 1 & Reliable \\
8 & 15 & 0.9475 & 94.75 & 11 & 0 & 0 & Reliable \\
9 & 13 & 0.8125 & 81.25 & 6 & 0 & 0 & Reliable \\
10 & 13 & 0.8125 & 81.25 & 13 & 0 & 0 & Reliable \\
11 & 14 & 0.875 & 87.5 & 1 & 0 & 2 & Reliable \\
12 & 13 & 0.8125 & 81.25 & 3 & 1 & 2 & Reliable \\
$\sum$ & 158 & 0.8229 & 82.29 & 99 & 6 & 10 & \\
\hline
\end{tabular}

Tabel 1. Adegan Body Shaming di Ruang Publik Serial Insatiable (Peneliti, 2019)

Seperti yang terlihat dari tabel di atas, terdapat total sebanyak 158 kali adegan body shaming yang muncul di ruang publik dalam serial Netflix Insatiable. Perilaku body shaming yang paling banyak ditampilkan dalam serial Netflix Insatiable di ruang publik ada di indikator lisan yaitu sebanyak 99 kali disusul indikator perbuatan sebanyak10 kali dan indikator tulisan sebanyak 6 kali.

Berdasarkan tes uji reliabilitas unsur body shaming di ruang publik di keseluruhan episode Serial Insatiable pada episode 4, dapat ditegaskan bahwa terjadi reliabilitas penilaian antara pengkoding 1 (N1) dan pengkoding 2 (N2) yaitu koefisien reliabilitas mencapai 68,5\%. Dalam episode ini hanya mencapai persentase yang sedikit yaitu sebanyak 68,5\% karena dalam episode tersebut hanya sedikit adegan yang memiliki undur body shaming. Meskipun menunjukan persentase yang sedikit, namun hasil pengkodingan dari dua pengkoding hampir mendekati jumlah nilai yang sama. Sehingga hasil pengkodingan dari dua pengkoding memiliki tingkat kesepakatan dan cara pandang yang rendah, namun tidak reliabel. 


\begin{tabular}{cccccccc}
\hline Eps & M & CR & $\%$ & Lisan & Tulisan & Perbuatan & Keterangan \\
\hline 1 & 15 & 0.882 & 88.2 & 43 & 2 & 10 & Reliabel \\
2 & 15 & 0.882 & 88.2 & 18 & 1 & 3 & Reliabel \\
3 & 16 & 0.941 & 94.1 & 12 & 0 & 0 & Reliabel \\
4 & 12 & 0.705 & 70.5 & 6 & 0 & 0 & Reliabel \\
5 & 14 & 0.823 & 82.3 & 25 & 0 & 0 & Reliabel \\
6 & 17 & 1 & 100 & 1 & 0 & 0 & Reliabel \\
7 & 16 & 0.941 & 94.1 & 4 & 0 & 0 & Reliabel \\
8 & 14 & 0.823 & 82.3 & 1 & 0 & 0 & Reliabel \\
9 & 17 & 1 & 100 & 8 & 0 & 0 & Reliabel \\
10 & 17 & 1 & 100 & 4 & 0 & 0 & Reliabel \\
11 & 14 & 0.823 & 82.3 & 7 & 0 & 0 & Reliabel \\
12 & 14 & 0.823 & 82.3 & 6 & 0 & 1 & Reliabel \\
$\sum$ & 181 & 0.887 & 88.7 & 135 & 3 & 14 & \\
\hline
\end{tabular}

Tabel 2. Adegan Body Shaming di Ruang Privat Serial Insatiable (Peneliti, 2019)

Seperti yang terlihat dari tabel di atas, terdapat total sebanyak 181 kali adegan body shaming yang muncul di ruang privat dalam serial Netflix Insatiable. Perilaku body shaming yang paling banyak ditampilkan dalam serial Netflix Insatiable di ruang privat ada di indikator lisan yaitu sebanyak 135 kali disusul indikator perbuatan sebanyak14 kali dan indikator tulisan sebanyak 3 kali.

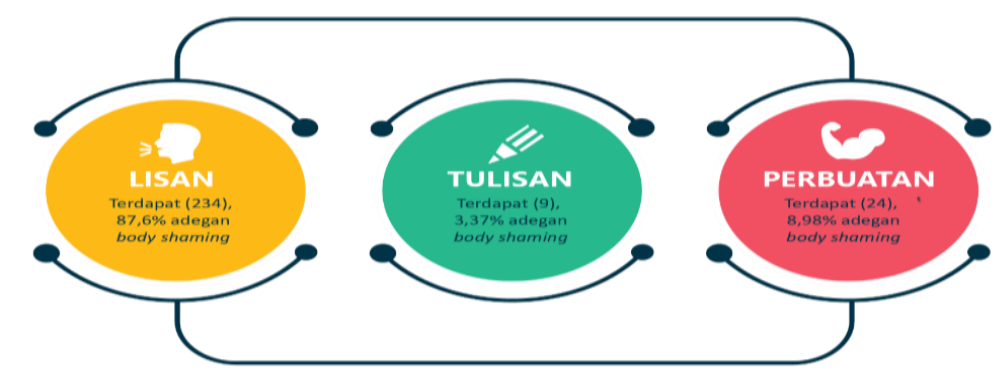

Gambar 1. Data Indikator Body Shaming yang ditemukan dalam Serial Netflix Insatiable (Peneliti, 2019)

Dalam penelitian ini, perilaku body shaming yang paling banyak muncul adalah dalam indikator lisan dengan bentuk menjuluki yaitu perbuatan memberi nama ejekan berdasarkan karakter fisik seseorang baik secara personal maupun di ruang publik. Indikator lisan mengambil porsi sebesar $87,6 \%$ dari seluruh adegan body shaming yang muncul dalam serial Netflix Insatiable. Sedangkan indikator perbuatan berada di posisi kedua dengan porsi sebesar 8,98\% dengan bentuk adegan memberikan ekspresi kaget melihat karakter, bentuk fisik seseorang. Kemudian indikator tulisan muncul sebanyak 3,37\% dalam bentuk adegan mencorat-coret, menggambarkan, menuliskan nama julukan atau ejekan mengenai bentuk atau karakter fisik seseorang.

Indikator body shaming lisan memiliki porsi paling besar daripada porsi indikator yang lain karakteristiknya hampir sama seperti perilaku bullying verbal dilakukan dengan cara komunikasi sehingga begitu mudah dilakukan dan dikatakan begitu saja di depan orang-orang terdekat seperti teman bahkan hingga ke orang dewasa. Tidak melukai fisik namun mematahkan semangat dan kepercayaan diri seseorang yang menerimanya. 


\section{KESIMPULAN}

Demikianlah temuan data dan analisis serta interpretasinya dalam penelitian Kecenderungan Perilaku Body Shaming dalam Serial Netflix Insatiable ini. Setelah dilakukan penelitian, ditemukan bahwa indikator perilaku body shaming terbanyak dalam serial ini adalah indikator lisan mencapai angka paling tinggi yaitu $87,6 \%$ atau sebanyak 234 adegan. Yang kedua persentase perilaku body shaming yang terdapat dalam serial ini diperoleh $82,29 \%$ dilakukan di ruang publik. Kemudian perilaku body shaming dalam ruang privat dimunculkan sebesar $88,7 \%$ dari 12 episode serial ini.

Peneliti berharap untuk ke depannya, dapat dilakukan penelitian mengenai studi kasus body shaming sehingga dapat menjelaskan fenomena body shaming lebih mendalam. Hal ini akan berguna sebagai evaluasi bagi para pembuat serial, apakah serial ini membawa pesan yang positif seperti yang mereka harapkan untuk membantu memberikan pemahaman dan meningkatkan kesadaran penontonya akan perilaku body shaming ataukah malah membawa dampak buruk yang ternyata menimbulkan interpretasi negatif atau bertolak belakang dengan maksud pembuat serial sebenarnya.

\section{REFERENSI}

Adelia Marista Safitri. (2018). Sering Tidak Sadar, Ini 4 Tanda Anda Suka. Retrieved September 27, 2019, from Hellosehat website: https://hellosehat.com/hidup-sehat/psikologi/ciri-bodyshaming-adalah/

Anggraeni, B., Pranayama, A., \& Sutanto, R. P. (2018). Perancangan Kampanye "Sizter's Project" sebagai Upaya Pencegahan Body Shaming Brigitta. 1-9.

Choma, B. L., Shove, C., Busseri, M. A., Sadava, S. W., \& Hosker, A. (2009). Assessing the role of body image coping strategies as mediators or moderators of the links between self-objectification, body shame, and well-being. Sex Roles, 61(9-10), 699-713. https://doi.org/10.1007/s11199. 009-9666-9

Coloroso, B. (2003). The Bully, The Bullied, and The Bystander Breaking the Cycle of Violence. Srsd119.Ca. Retrieved from https://srsd119.ca/parentinformationfiles/SafeSchoolsfiles/kidsareworthitBarbaraColoroso.pd $\mathrm{f}$

Eriyanto. (2011). Analisis Isi Pengantar Metodologi Penelitian Ilmu Komunikasi dan Ilmu-ilmu Sosial Lainnya. Jakarta: Kencana Prenada Media Group.

Farrell, A. E. (2011). Fat Shame, Stigma and The Fat Body in American Culture. Newyork: NEW YORK UNIVERSITY PRESS.

Maigoda, T. C., \& Briawan, D. (2013). STUDI KUALITATIF PERSEPSI CITRA TUBUH REMAJA YANG KURUS DAN GEMUK SERTA UPAYA UNTUK MENCAPAI TUBUH IDEAL PADA SISWI SMA NEGERI 1 KOTA BOGOR. Jurnal Kesehatan, 6, 15-28.

Muhsin, A. (2014). Studi Kasus Ketidakpuasan Remaja Putri terhadap Keadaan Tubuhnya (Body Image Negative pada Remaja Putri). Universitas Negeri Yogyakarta.

Perebinosoff, P., Gross, B., Gross, L. S. (2005). Programming for TV, Radio, and the Internet: Strategy, Development, and Evaluation. UK: Elsevier.

Putra, Sandy Arista, \& Rusdiana, E. (2019). Kualifikasi Tindak Pidana Atas Perbuatan Body Shaming oleh Netizen. Jurnal Trunojoyo, 1, 31-42.

Sakinah. (2018). "Ini Bukan Lelucon”: Body Shaming, Citra Tubuh, Dampak dan Cara Mengatasinya. Jurnal Emik, 1, 53.

Widodo, A. (2016). Komunikasi Bully. VI(1).

Yayasan Semai Jiwa Amini. (2008). Bullying: Mengatasi Kekerasan di Sekolah dan Lingkungan Sekitar Anak. Jakarta: Grasindo. 